\author{
NBER WORKING PAPER SERIES \\ ON \\ HISTORICAL FACTORS IN LONG RUN GROWTH
}

\author{
WERE FREE SOUTHERN FARMERS \\ "DRIVEN TO INDOLENCE" BY \\ SLAVERY? A STOCHASTIC PRODUCTION \\ FRONTIER APPROACH
}

\author{
Elizabeth B. Field-Hendrey \\ Lee A. Craig
}

\begin{abstract}
Historical Paper 82
NATIONAL BUREAU OF ECONOMIC RESEARCH

1050 Massachusetts Avenue

Cambridge, MA 02138

April 1996
\end{abstract}

The authors thank Michael Edelstein, Ray Palmquist, V. Kerry Smith, and David Weiman for helpful comments on an earlier draft. This paper is part of NBER's research program in the Development of the American Economy. Any opinions expressed are those of the authors and not those of the National Bureau of Economic Research.

(C) 1996 by Elizabeth B. Field-Hendrey and Lee A. Craig. All rights reserved. Short sections of text, not to exceed two paragraphs, may be quoted without explicit permission provided that full credit, including $\odot$ notice, is given to the source. 
NBER Historical Paper 82

April 1996

\title{
WERE FREE SOUTHERN FARMERS \\ "DRIVEN TO INDOLENCE" BY \\ SLAVERY? A STOCHASTIC PRODUCTION \\ FRONTIER APPROACH
}

\begin{abstract}
Antebellum critics of slavery argued that it was responsible for the relative inefficiency of free southern farms. We examine this issue, employing a stochastic production function, which allows us to distinguish between technological superiority and technical inefficiency, and controlling for crop mix, which we treat as endogenous. We find that although large plantations enjoyed a technological advantage, slave farms were less efficient than free northern farms but more efficient than free southern farms. In addition, free southern farms were significantly less efficient than comparable northern farms.
\end{abstract}

Elizabeth B. Field-Hendrey

Department of Economics

Queens College

Flushing, NY 11367
Lee A. Craig

Department of Economics

North Carolina State University

Raleigh, NC 27695-7506

and NBER 
The relative efficiency of slave agriculture in the American South has stimulated comment and speculation since the mid-nineteenth century (see Cairnes, [1862] 1962; Olmsted, [1861] 1953; Gray, 1941). In particular, contemporary observers claimed that free farmers in the antebellum South were inherently less efficient than other farmers - that is, they were "driven to indolence" according to Frederick Law Olmsted ([1861] 1953, p. 104). More recently economists have applied increasingly sophisticated statistical techniques to investigate that claim. ${ }^{1}$ Despite the vast literature on the subject, no one has directly tested this hypothesis. To reject it necessitates a comprehensive comparison of the efficiency of North v. South, Old South v. New South, and free v. slave farms, employing econometric techniques designed for such a task. ${ }^{2}$

This paper employs a stochastic production frontier to compare all of the abovementioned farm types and regions. We utilize similar measures of farm output, which have differed in previous studies of northern and southern agriculture, and we control for the effect of variation in cotton's share of output. In the next section we discuss in detail the issues involved in the debate over the relative efficiency of southern agriculture. Section II contains a description of the data and variables employed. Section III describes the empirical

${ }^{1}$ The evolution of the debate and techniques employed can be followed chronologically in Fogel and Engerman (1974), David and Temin (1979), Wright (1979), Field (1988), Grabowski and Pasurka (1989) and (1991), Hofler and Folland (1991), and Field-Hendrey (1995).

${ }^{2}$ In addition, the effects of variations in crop mix across regions and farm types on efficiency have not been resolved. See

David and Temin (1979), Wright (1979), and Schaefer (1983) for expositions on this issue. 
tests and results, and the final section examines implications for the historiography and economic interpretation of American slavery.

\section{ISSUES}

Antebellum critics of slavery argued that the existence of the "peculiar institution" was responsible for the inefficiency of free southern farms. Olmsted claimed that "the proportion of free (southern) white men who live as well in any respect as our working classes in the North, on an average, is small ... ([1861] 1953, pp. 11-12)." John Elliot Cairnes argued that northern yeomen farmers had an inherent productivity advantage over southern free farmers because an owner-operator growing cereal crops and "appropriating the whole produce of his toil, needs no other stimulus to exertion," but the production of southern staples "requires for its efficient conduct that labour should be combined and organized on an extensive scale", and the production of cotton, tobacco, rice, and sugar "favour(s) the employment of slaves in the competition with peasant proprietors (Cairnes, [1862] 1962, pp. 41-42)". These observations imply that although free northern farms may have been as efficient as southern plantations, free southern farms were not as efficient as free northern farms.

Similarly, in this century Lewis Cecil Gray reasoned that since planters could "produce at price levels that left little more than the expense of maintaining the slave, white labor could bid no lower (1941, p. 474)." He went further and argued that the geographical concentration of slaves in the most fertile areas and the areas most conducive to marketing manifested the planters' ability to pay a premium above that of free farmers for the 
acquisition of land, and this outcome put free southern farms at a productive disadvantage (Gray, 1941, pp. 474-75). Indeed, all of these authors describe the lowly condition of free southern agriculture and the "mean whites", "crackers", or "white trash" who inhabited the rural south (Gray, 1941, pp. 483-87; Olmsted, 1953, pp. 65-66 and 87; Stampp, 1956, p. 338 and 380; Cairnes, 1962, pp. 54-56).

Robert Fogel and Stanley Engerman addressed the above arguments and found that slave agriculture was more efficient than free agriculture in either the North or the South (Fogel and Engerman, 1974). Fogel and Engerman (FE) argue that the division of labor afforded by the sowing and cultivation of cotton was realized on neither southern non-slave farms nor the primarily mixed (grain and livestock) producing farms of the North. This argument in fact revolves around the use of slave labor in gangs on large (greater than 15 slaves) farms and implies that these large farms would have been more efficient than either small slave farms or free farms. In addition, FE argue that free farms, both in the North and the South, were less efficient than small slave farms, based on their calculations of factor productivity indices. FE reach these conclusions based on a comparison of total factor productivity (TFP) indices for slave farms of various sizes (measured by numbers of slaves owned) and for free southern farms, in the New and Old South, as well as for northern farms. This approach is quite comprehensive and considers all regions and farm types, but it has been heavily criticized for the overly aggregate level of the analysis, and for the fact that FE do not control for wide variations in crop mix.

Elizabeth Field (1988) estimates a flexible form production function (the translog) from the micro-level data available from the manuscript censuses. She shows that large slave 
farms were more efficient than small (non-gang) slave farms, and that the marginal productivity of slave labor was greater on large plantations than small ones. Richard Hofler and Sherman Folland (1991) refine Field's approach by employing a stochastic production frontier approach to analyze the relative efficiency of slave agriculture. A stochastic production frontier specifies a one-sided error term, which more accurately reflects production technology than the usual deterministic production frontier, since farms could not achieve more than best practice techniques, but could certainly achieve less. It allows one to distinguish between technological superiority (a higher frontier) and inefficiency (the extent to which a farm falls below that frontier).

Richard Grabowski and Carl Pasurka (1989) also use a stochastic production frontier; however, Grabowski and Pasurka (GP) treat all slave farms as having a common production technology, and they employ a Cobb-Douglas production function, which Field (1988) demonstrates to be unacceptable. Hofler and Folland (HF) compare large and small slave farms, employing the translog functional form but with a stochastic production frontier. They find that large slave farms, which employed the gang system of labor organization, were technologically superior to small slave farms, but they also find that large slave farms displayed greater inefficiency, which was, however, outweighed by the technological advantage of the gang system. Although it represents a significant methodological improvement, HF's analysis suffers from the same limitation as Field (1988), because it only considers slave farms, and it does not control for cotton's share of output. Field-Hendrey (1995) broadens HF's approach by considering free as well as slave farms, and by including 
cotton share as an independent variable in the production function. ${ }^{3}$ The findings indicate that large slave farms were technologically superior to free and small slave farms, but that small slave farms did not enjoy any technological advantage over free farms. Free farms fell furthest below their production frontier, while large and small slave farms were equally efficient.

All of these comparisons, however, are limited to southern farms; thus they do not answer the larger question posed in the title of this paper: were free farmers in the South "driven to indolence?" Free southern farmers were in fact profoundly affected by the presence of slavery. First, as pointed out by Gray, free farmers farmed less well-located, less productive lands. Second, free farmers may well have been on the bottom rung of an agricultural ladder. Farmers with managerial skills, and without a moral aversion to slaveownership, might have aspired to climb that ladder, the top rung of which was plantation ownership. Such a process would have left the lower rungs occupied by those who maintained qualms about slavery or who lacked some combination of experience, wealth, initiative or ability. In order to draw conclusions about the efficiency of slave agriculture and free agriculture in the absence of slavery, a better comparison is of northern free farmers to southern slaveowners.

To answer this question, it is necessary to consider data from the North as well as the South, which we do below. No attempt has been made since Fogel and Engerman's Time on the Cross to compare northern and southern farms directly. We believe that our comparison

${ }^{3}$ Field-Hendrey treats cotton share as if it were exogenous, which may not be a valid assumption, since a farmer would have chosen desired output and cotton share simultaneously. 
is a significant improvement over FE's for three reasons. First, we use micro-level data, rather than aggregating, as did FE. Second, we use a stochastic production frontier, allowing us to separate issues of technological advantage from inefficiency. Finally, we not only control for cotton share, but also correct for the endogeneity of that variable, in order to address the problem of comparison of large slave farms with northern farms, which did not grow cotton, or with small slave farms or free farms in the South, which grew less cotton than the large slave farms.

Like the studies cited above, our measure of output is really revenue, not physical output, since we aggregate the crops and products reported in the Census, weighted by prices. Thus any measurement of efficiency shows efficiency in producing revenue, not truly technical efficiency. This problem was first pointed out by David and Temin (1979). The crux of the issue is that the cotton share of output increased with the number of slaves held (see Table 1) and 1859 may have been an exceptionally good year for cotton, both in terms of yield and price (Wright, 1979). Donald Schaefer (1983) suggests that the high yields occurred primarily in the New South, and that the Old South had a relatively poor cotton crop in 1859. Using a total factor productivity approach similar to FE's, Schaefer concludes that much of the "efficiency" advantage enjoyed by slave agriculture is a result of the atypical crop year. Thus large slave farms, especially in the New South, might have had higher revenue based on the high price of cotton and the high cotton share, not based on technical superiority.

Schaefer (and Wright) raise valid concerns; however, Schaefer's approach, being modelled on FE's, is quite aggregate. In addition, as Schaefer acknowledges, he does not 
correct for the possibility that not only yield, but price, was extraordinarily high. We believe that our method is preferable in this case, because by including predicted cotton share as an independent variable in the production function, we can predict what output would have been even if the farm grew no cotton. We separate Old and New South to allow for the possibility that desired cotton share had different effects on output by region, as suggested by Schaefer. Although our measure of output is still revenue, the main difficulty in inferring technical efficiency differences from revenue differences stems from the increase in the percentage of revenue derived from cotton as the number of slaves increased. Controlling for this effect allows us to directly compare the efficiency of North v. South, Old South v. New South, and free v. slave farms, and to draw conclusions about the efficiency of slave agriculture relative to free agriculture, both in the presence and in the absence of slavery.

\section{DATA AND VARIABLES}

We draw our sample of northern farms from the Bateman-Foust sample of rural households drawn from the manuscript censuses for 1860. (See Atack and Bateman, 1987, Appendices to ch. 2 and 7 for a description of the sample.) For the South, we used the Parker-Gallman sample, which is described in Gallman (1970). We exclude all farms with nonpositive values of output or any of the inputs. We have made input and output definitions comparable for the North and South, which entailed modifications of the measures used in previous studies of the regions such as FE (1974), Field (1988), and Craig (1991, 1993). Our measure of output is the market value of all crops reported by quantity in the Census, evaluated at regional prices, and the value of meat output. For the North, this is taken to be 
the reported value of animals slaughtered, but for the South we compute meat output according to the formulas given in Field (1985). Unlike FE and Field, we also include estimates of output not recorded in the Census, such as lumber, poultry and eggs. ${ }^{4}$

Our labor inputs are free and slave prime age male equivalent labor. The weights used in the computation of the northern labor force are described in Craig (1993); for the South we apply weights derived from FE (1974) to each of these groups. ${ }^{5}$ We exclude farms with very high or low output to labor ratios, in order to avoid including farms which had substantial hired labor which is not captured in our free labor measure, as well as farms where residents actually worked on other farms, and would be incorrectly included in the labor force of their home farm. Our capital input is the sum of the value of farm machinery

${ }^{4}$ This is the measure of output used in Craig $(1991,1993)$ and Craig and Field-Hendrey (1993) except that we do not include capital gains on land. Since the Parker-Gallman sample does not include the value of real estate, we cannot distinguish tenants from owners. Since slave owners were probably more likely than average to be owners (especially large slaveowners), there is a bias against finding any advantage for slave farms, and would strengthen such a finding. In addition, we do not include the value of home manufactures in the South, since FE suggest that were problems with this variable; however, the average value of home manufactures in the Bateman-Foust sample was only seven dollars. Finally, we regress this new definition of output on Field's earlier measure, which is based much more closely on FE's, and exclude any farms with a studentized residual above 1.5 or below -1.5 in order to exclude farms with unreasonable values of imputed output.

${ }^{5}$ The Bateman-Foust and Parker-Gallman samples were drawn differently. BatemanFoust is a cluster sample that contains all of the households in a township, including farm laborers not resident on farms; however, Parker-Gallman includes only those workers residing on a sampled farm. Because of this difference and in an attempt to make the samples as comparable as possible, we have not adjusted Northern farm labor for off-farm labor. 
and equipment reported in the Census, the imputed value of farm buildings, and the value of livestock. Our land inputs are improved and unimproved acreage. ${ }^{6}$

Table 1 contains the means and definitions of the variables, for all farm types (free, small slave and large slave) and regions (Old and New South, and North). Northern farms were larger than free farms in either region, but smaller than slave farms, large or small. Compared to the North, southern farms had a smaller percentage of improved acreage. Farms in the New South were larger and grew more cotton than farms in the Old South.

\section{METHODOLOGY AND EMPIRICAL RESULTS}

We use the stochastic production frontier developed in Aigner, Lovell and Schmidt (1977) and outlined in HF (1991), whose notation we follow:

$\ln Q_{i j}=g_{j}\left(\operatorname{lnF}_{j}, \ln S_{j}, \operatorname{lnK}_{j}, \operatorname{lnI}_{j}, \ln U_{j}, P C O T_{j}\right)+v_{i j}-u_{i j}$

$i=\quad$ Old South small slave, Old South large slave,

New South small slave, New South large slave,

$\mathrm{j}=1, \ldots, \mathrm{n}_{\mathrm{i}}$

for slave farms,

$\ln Q_{i j}=g_{i}\left(\ln F_{j}, \ln K_{j}, \ln I_{j}, \ln U_{j}, P C O T_{j}\right)+v_{i j}-u_{i j}$

$\mathrm{i}=$ free Old South, free New South,

$\mathrm{j}=1, \ldots, \mathrm{n}_{\mathrm{i}}$

for free farms, and

${ }^{6}$ Acreage is used, rather than a land input adjusted by a soil quality index, such as that described in Field (1988) for the South, because it is not possible to construct a comparable index for the northern sample. 
$\ln Q_{i j}=g_{j}\left(\ln F_{j}, \ln K_{j}, \ln I_{j}, \ln U_{j}\right)+v_{i j}-u_{i j}$

$\mathrm{i}=$ North,

$\mathrm{j}=1, \ldots, \mathrm{n}_{\mathrm{i}}$

for northern farms.

We employ a translog production function in which $\mathrm{Q}$ is output; $\mathrm{F}$ is free labor; $\mathrm{S}$ is slave labor; $\mathrm{K}$ is capital; $\mathrm{I}$ is improved acreage; and $\mathrm{U}$ is unimproved acreage. PCOT is predicted cotton share, which is obtained by regressing cotton share for each farm group on $\mathrm{F}, \mathrm{S}, \mathrm{K}, \mathrm{I}$ and $\mathrm{U}$, as well as state dummies included to capture intraregional differences in cotton share. Since cotton share is bounded by 0 and 1 , we obtain our estimates by TOBIT regressions. Parameter estimates for the cotton share equations and the production frontiers are reported in the Appendix. Also, $\mathrm{u}$ is a one-sided error term, measuring the extent to which actual revenue falls short of maximum potential (frontier) revenue, and $v$ is assumed to have a normal distribution, while $\mathrm{u}$ is assumed to have a half-normal distribution.

We compare farm groups in two ways. First, we compare the average predicted frontier output for each group to the output that would have been produced if the farmer followed a different technology, for example, if slaves had been treated as free workers. This comparison tells us which technologies were superior; however, the farmer would also have to consider how close to this frontier he was likely to get - that is, his technical inefficiency. We also compare the average values of our inefficiency measure for each group. The final question is, if some methods of production were technologically superior, but had higher inefficiency, did the technological advantage outweigh the disadvantage of 
higher inefficiency? We combine our estimates of frontier (or best possible) output with our measures of inefficiency in order to answer this question.

\section{A. Technological Superiority}

We first consider the possible technical advantage of large slave farms, since the use of the gang system on these farms is at the heart of FE's contention that slave agriculture was more efficient than free farming. In order to determine whether gang-system farms were indeed technologically superior to other types of farms, as FE contend, we compute average predicted frontier output for large slave farms, and compare it to average predicted output using the northern farm frontier, and the small slave farm frontiers and free southern farm frontiers. ${ }^{7}$ We do this comparison both for Old and New South, and, in addition, for large slave farms in each region, we compute the predicted frontier output had those farms been located in the other region of the South. The average predicted values are reported in Table 2. We provide predicted means using the mean value of PCOT, as well as predicted means if the cotton share were set equal to zero, in order to obtain a prediction for output if the farm grew no cotton. Comparing predicted outputs with a zero cotton share ought to truly compare technological superiority, not superiority in producing revenue. We test the hypotheses that the predicted frontier output of large slave farms in each of the regions was less than or equal to predicted output using the frontier for different groups, with and without

\footnotetext{
${ }^{7}$ As HF did, we evaluate each of the production frontier functions at the means of the log values of the inputs, yielding the mean of the logarithm of predicted frontier output.
} 
setting cotton share to zero. ${ }^{8}$ In both regions, we reject the hypothesis for all groups, with several exceptions. In the Old South, we cannot reject the hypothesis that large slave farm frontier revenue was less than or equal to northern farm revenue if cotton share was set to zero. We also conclude that these farms would have enjoyed greater output had they been located in the New South, whether or not we set cotton to zero. In the New South, large slave farms had significantly higher frontier output than all groups, except New South free farms, when cotton shares were set to zero. ${ }^{9}$ Generally, we conclude that large slave farms enjoyed a technological advantage over all other farm types, free and slave, northern and southern, in both regions, even if cotton share was set to zero.

Next, we consider small slave farms, in order to determine whether there was an efficiency gain associated with slavery per se, even when the farm was too small to make employment of the gang system practical. We compare predicted average frontier revenue in both regions of the South to each other, and to free farm output in the North and the relevant region of the South. Small slave farms in the Old South had no advantage over other farm types. In this region, small slave farms are predicted to have slightly higher frontier output than if they operated as free farms, (with cotton share set at its mean value) but the difference is not significant. Even including the cotton advantage, small slave farms in the Old South had lower predicted output than they would have enjoyed in the North, or in the New South. In addition, once cotton share is set to zero, small slave farms in the Old South

\footnotetext{
${ }^{8}$ The $\mathrm{t}$ statistics are available from the authors on request.

${ }^{9}$ Free farms in the New South had a negative coefficient on the predicted cotton share, which meant that setting cotton share to zero actually raised frontier output; however, this coefficient was not significantly different from zero.
} 
could have had higher frontier output had they been free farms. The picture in the New South is slightly different. Small slave farms did enjoy a significant advantage over free farms in the New South and in the North, when cotton share is set at its mean value; however, it cannot be concluded that this is a technological advantage, for once cotton share is set to zero, the advantage disappears.

We next consider free farms. One possible reason for the observation that nonslaveowning farmers in the South were not as well off as those in the North could be that they were operating on a lower production possibility frontier. We compare free farms in the Old and New South to each other and to the northern farm frontier. Old South free farms would have had higher predicted frontier output had they been located in the North or in the New South, whether or not cotton is excluded. New South free farms had higher predicted output than Old South free farms, but lower predicted output than northern farms, again regardless of whether cotton share is set to zero. Finally, northern farms are predicted to have higher output than Old South free farms, (although the difference was not significantly different from zero) but significantly lower output than had they been free farms in the New South. Overall, we do not find that northern farms enjoyed technological superiority over southern free farms. Contemporary observations about the lowly condition of the southern farmers do not appear to be founded on a technological disadvantage.

\section{B. Technical Inefficiency}

The question of technological superiority at the frontier is only part of the story, however. Slave farms could have enjoyed a technological advantage, but still fallen so far 
below their frontiers as to negate the advantage. Southern free farms could potentially have produced as much output as a northern farm of equal size and labor force, but in practice could have produced much less due to inefficiency. Therefore, next, we consider how close to these frontier outputs a farmer in each group was likely to come. Average technical inefficiency for each farm group is presented in Table 3. The measure is calculated as the mean of $\mathrm{u}_{\mathrm{ij}}$ for that group. The group with the lowest inefficiency, that is the one that achieved the highest percentage of possible output, was the North. In the South, all groups in the Old South had lower inefficiency than in the New South, which might tend to negate the technological advantage we found in the New South. Within each of the southern regions, as slaveholding increases, mean inefficiency first declines, and then increases, suggesting that slaveholding initially conferred an efficiency advantage, but that as slave holding increased, that advantage declined, perhaps because of increased shirking by slaves, and increased monitoring costs. Southern free farmers were less efficient than northern free farmers, and less efficient than small slave farms, although more efficient than large slave farms.

This comparison of means may be misleading, however. Even within the North, inefficiency decreased as farm size and output rose. Since free farms in the South were smaller than northern farms, perhaps they appear less efficient merely due to their small size. A more interesting comparison would be of free farms in the South to comparably sized farms in the North. The same problem affects comparison of free southern farms to slave farms, since slave farms were, on average, much larger. In order to control for these differences, we regress the residuals from the frontiers for all groups and regions, which is 
our measure of inefficiency, on output, number of slaves held, and the cotton share of output. We expect the coefficient on output to be negative, indicating that larger farms were more efficient (lower inefficiency). We include the number of slaves in order to test the hypothesis that increases in slaveholding would have also increased inefficiency due to shirking and monitoring costs, resulting in a positive coefficient on the slaveholding variable. We also include two regional dummy variables, NEWSOUTH, and NORTH, to ascertain whether differences in inefficiency remained even after output was held constant. If so, the coefficient on NEWSOUTH should be positive, and that on NORTH, negative. In addition, we include a dummy variable, DSLAVE, which took the value one, if there were any slaves on the farms, and a dummy variable, DGANG, with the value one for farms with sixteen or more slaves (FE's cutoff for use of the gang system). Finally, we include several regional variables interacted with the cotton share in order to account for the fact that 1859 was an unusually good year for cotton in certain areas of the New South, although not for the South as a whole. ${ }^{10}$ Higher than normal cotton yields should manifest themselves as lower residuals from the best practice frontier. In keeping with Schaefer's (1983) observations we interact a dummy variable for Alabama, Mississippi and Louisiana, one for Arkansas, one for Texas, and one for the rest of the New South, with the cotton share, to see if farms with higher cotton shares in the New South showed lower inefficiency.

${ }^{10}$ Schaefer finds that cotton yield was about 25 percent higher than normal for the New South as a whole, and was especially good in Louisiana, Mississippi and Alabama, but only 13 percent above normal for Arkansas, and actually lower than normal in Texas (Schaefer, 1983, pp. 859-862). 
The regression coefficients are presented in Table 4. Since northern and southern observations come from different samples, we weight each observation by the ratio of the number of sampled farms in a region divided by the total number of farm reported in the Census for that region. The results are generally as expected. The coefficient on output is negative, but it is not significantly different from zero, indicating that there was no relationship between size and efficiency. Farms in the New South show greater inefficiency, ceteris paribus, but farms growing more cotton in the various subregions of the New South come closer to their frontiers, although the coefficient for Texas is not significantly different from zero, consistent with Schaefer's finding that Texas did not experience a good cotton year in 1859 , although the rest of the New South did. The findings for the slaveholding variables indicate that owning slaves allowed farmers to reach a higher percentage of best practice output, that operating a gang system plantation conferred a further efficiency advantage, but that this advantage was gradually eroded by increased inefficiency associated with the numbers of slaves held. A farm located in the North achieved a higher percentage of potential output, even when output is held constant, which supports the hypothesis that southern free farmers were "driven to indolence."

\section{Technological Advantage V. Inefficiency}

Finally, we combine our findings on predicted frontier output, and on inefficiency, the degree to which farms fell below that frontier, in order to see which farms enjoyed an advantage in practice, and to what extent any advantage was explained by the ability to grow cotton. To predict actual output (as opposed to frontier, or potential output), we take the 
predicted mean frontier revenues for each group and subtract the mean inefficiency for that group. We also compute a counterfactual output for each farm in group A, if it had fallen into group B, to see whether, in practice, a group A farm would have been better off in group B. This is the question that would have been relevant to the farmer; a farmer would not care if he had an efficiency advantage if that did not result in higher output in practice. In order to make this comparison, we take the predicted frontier output for group A using the group B frontier, from Table 2, and subtract from that the predicted inefficiency for a farm with group A characteristics, but which fell in group B. ${ }^{11}$ We predict inefficiency from the results in Table 4, which is preferable to simply assigning the mean inefficiency for group B to group A, since groups A and B presumably differed on average, by farm size and crop mix, so that even if group A farms all behaved as if they were in group B, they still would not have the same inefficiency, on average, as group B farms, unless they had identical characteristics. Thus if we predict how group A farms would have done using the group B production function, we must also predict what their average inefficiency would have been.

We look first at large slave farms. In the Old South, these farms are predicted to have higher output than small slave farms or free farms in the region, when differences in inefficiency were accounted for, but gang farms in the Old South are predicted to have higher output using the northern farm function, whether or not cotton share was set to zero. In the New South, these plantations are predicted to have higher output in practice than small slave farms or northern farms, when cotton share is evaluated at its mean value, but lower

\footnotetext{
${ }^{11}$ It was not possible to compute standard errors for these predictions, but we felt that the comparison was worth examining nonetheless.
} 
output than free farms in the region. When cotton share is set to zero, plantations still have an advantage over small slave farms, but not over free farms in the region.

In the New South, small slave farms and free farms both are predicted to have higher output in practice than northern farms, but that advantage disappears when cotton share is set to zero. Also, small slave farms in that region are predicted to have higher output than if they had acted as free farmers, but again that benefit vanishes when the cotton effect was removed. In the Old South, we do not find any output gain over northern farms even when cotton is included. As in the New South, small slave farms did produce more than free farms with otherwise identical characteristics, if the cotton effect was included.

\section{SUMMARY AND CONCLUSIONS}

Large plantations in the antebellum South did have a technological advantage over smaller slave farms, and over free farms both in the North and the South, supporting FE's hypothesis that use of the gang system represented a superior technology only attainable through the employment of slave labor, and only practical when sixteen or more slaves were present. Gangsystem farms enjoyed this technical superiority even when the cotton share was set to zero. In addition, passing the sixteen slave threshold for use of the gang system led to a reduction in inefficiency. Not only did gang system farms have a higher frontier, but they achieved a higher percentage of frontier output. As slaveholding grew, however, inefficiency did likewise, perhaps due to shirking by slaves, and higher monitoring costs, to the point that large slave plantations had higher inefficiency on average than smaller slave farms, than northern farms, and, in the New South, than free southern farms. Even when this greater inefficiency is taken into account, 
large slave farms produced greater output in practice than they could have had they operated as small slave farms, or as free farms in the Old South or in the North, but, once the benefit of being able to grow cotton is removed, southern plantations would have had higher output had they operated as northern farms did. The effect of crop mix explains much of the edge possessed by plantation owners.

We found no technical advantage for small slaveowners. Although small slaveowners were able to reach a higher frontier than free farmers, the benefit is explained by the greater cotton share of output on such farms. Since FE's hypothesis revolves around use of the gang system, this is perhaps not surprising. We did find, however, that owning slaves resulted in a reduction in inefficiency, although that decrease was gradually offset by the effect of additional slaves. In practice, small slave farms were able to produce greater output than free farms with otherwise identical characteristics, but that ability was linked to their greater ability or willingness to grow cotton. Overall, then, we paint a mixed picture of the advantages of slave agriculture. Large slave plantations did have a technical edge due to use of the gang system, but slavery, per se, did not allow farms to reach a higher frontier, although it did allow them to produce a higher fraction of frontier output. In practice, gang system farms did produce higher outputs, but those higher outputs were possible mostly because of the crop mix.

We find that the presence of slavery had a significant impact on the free farms of the South. Although we did not find that northern farms had any technical advantage over southern free farms, a northern farmer could achieve a significantly higher fraction of frontier output than a free farmer in the Old South, and the effect is even more pronounced when a comparison is made to the New South. Because effective farm managers in the South had an incentive and 
better opportunities to become slaveowners, southern free farmers were less efficient than their northern counterparts. Thus poor southern whites were not "driven to indolence" by slavery in the manner perceived by Olmsted, but rather the opportunities provided by slavery left the "indolent" at the foot of the southern economic ladder. 


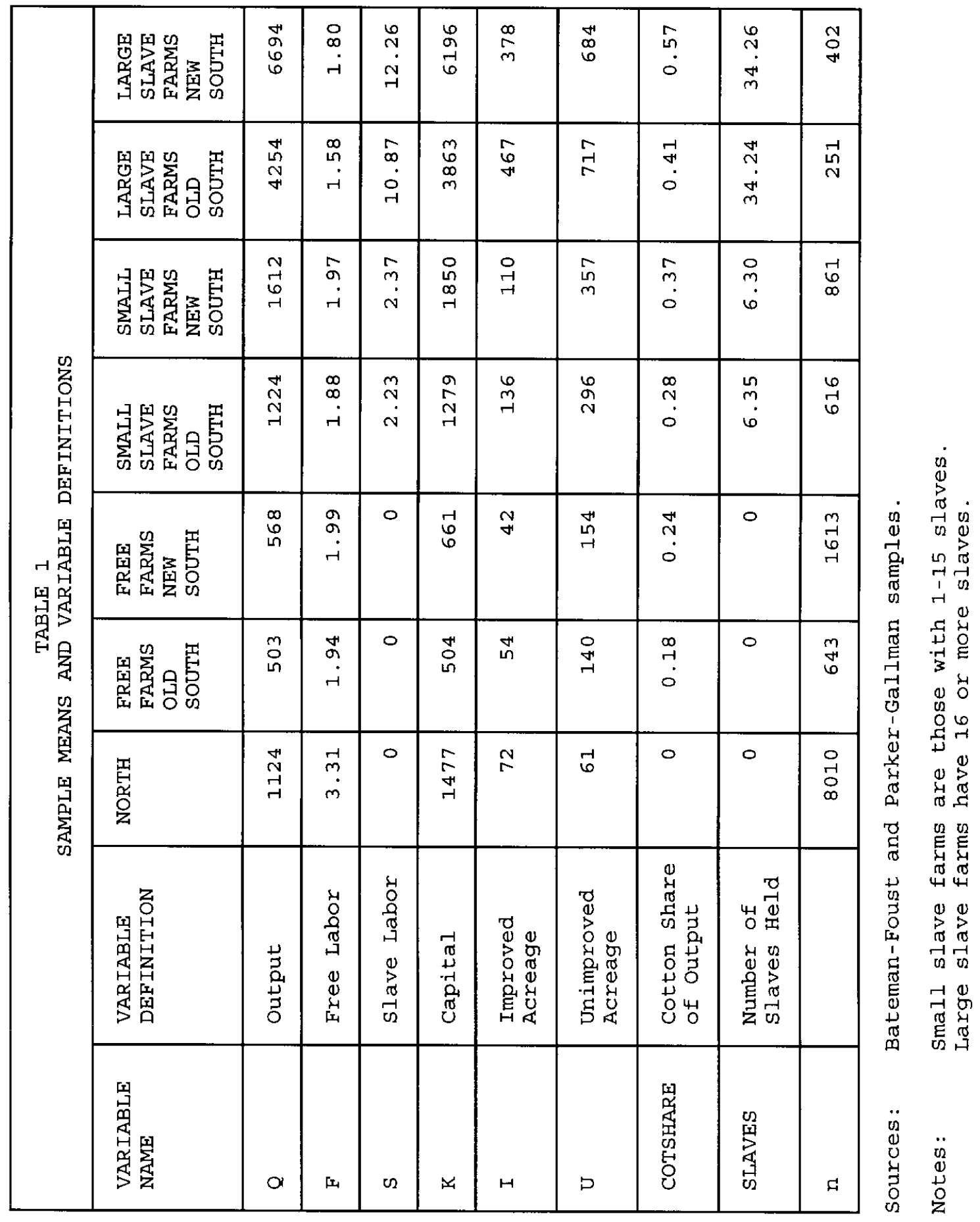




\begin{tabular}{|c|c|c|c|c|c|c|c|}
\hline \multicolumn{8}{|c|}{ MEAN PREDICTED FRONTIER REVENUES } \\
\hline & \multicolumn{7}{|c|}{ Farm Function Used: } \\
\hline $\begin{array}{l}\text { Evaluated } \\
\text { at Means } \\
\text { for: }\end{array}$ & North & $\begin{array}{l}\text { Free } \\
\text { old } \\
\text { south }\end{array}$ & $\begin{array}{c}\text { Free } \\
\text { New } \\
\text { South }\end{array}$ & $\begin{array}{l}\text { Small } \\
\text { Slave } \\
\text { old } \\
\text { South }\end{array}$ & $\begin{array}{c}\text { Small } \\
\text { Slave } \\
\text { New } \\
\text { South }\end{array}$ & $\begin{array}{c}\text { Large } \\
\text { slave } \\
\text { old } \\
\text { South }\end{array}$ & $\begin{array}{c}\text { Large } \\
\text { Slave } \\
\text { New } \\
\text { South }\end{array}$ \\
\hline $\begin{array}{l}\text { NORTHERN } \\
\text { FARMS }\end{array}$ & & & & & & & \\
\hline $\begin{array}{l}\text { PCOT set } \\
\text { at zero }\end{array}$ & 7.082 & 6.860 & 7.139 & -- & -- & -- & -- \\
\hline $\begin{array}{l}\text { FREE FARMS } \\
\text { OLD SOUTH }\end{array}$ & & & & & & & \\
\hline $\begin{array}{l}\text { PCOT } \\
\text { set at } \\
\text { mean }\end{array}$ & -- & 6.418 & 6.585 & -- & -- & -- & -- \\
\hline $\begin{array}{l}\text { PCOT set } \\
\text { at zero }\end{array}$ & 6.573 & 6.327 & 6.614 & -- & -- & -- & -- \\
\hline $\begin{array}{l}\text { FREE FARMS } \\
\text { NEW SOUTH }\end{array}$ & & & & & & & \\
\hline $\begin{array}{l}\text { PCOT } \\
\text { set at } \\
\text { mean }\end{array}$ & -- & 6.466 & 6.590 & -- & -- & -- & -- \\
\hline $\begin{array}{l}\text { PCOT set } \\
\text { at zero }\end{array}$ & 6.657 & 6.342 & 6.630 & -- & -- & -- & -- \\
\hline $\begin{array}{l}\text { SMALI } \\
\text { SLAVE } \\
\text { FARMS OLD } \\
\text { SOUTH }\end{array}$ & & & & & & & \\
\hline $\begin{array}{l}\text { PCOT set } \\
\text { at mean }\end{array}$ & -- & 7.215 & -- & 7.221 & 7.472 & -- & -- \\
\hline $\begin{array}{l}\text { PCOT set } \\
\text { at zero }\end{array}$ & 7.358 & 7.074 & -- & 6.958 & 7.340 & -- & -- \\
\hline
\end{tabular}




\begin{tabular}{|c|c|c|c|c|c|c|c|}
\hline & \multicolumn{7}{|c|}{$\begin{array}{l}\text { TABLE } 2 \text { (cont.) } \\
\text { Farm Function Used: }\end{array}$} \\
\hline $\begin{array}{l}\text { Evaluated } \\
\text { at Means } \\
\text { for: }\end{array}$ & North & $\begin{array}{l}\text { Free } \\
\text { old } \\
\text { South }\end{array}$ & $\begin{array}{c}\text { Free } \\
\text { New } \\
\text { South }\end{array}$ & $\begin{array}{l}\text { Small } \\
\text { Slave } \\
\text { old } \\
\text { South }\end{array}$ & $\begin{array}{c}\text { Small } \\
\text { Slave } \\
\text { New } \\
\text { South }\end{array}$ & $\begin{array}{l}\text { Large } \\
\text { Slave } \\
\text { old } \\
\text { South }\end{array}$ & $\begin{array}{c}\text { Large } \\
\text { Slave } \\
\text { New } \\
\text { South }\end{array}$ \\
\hline $\begin{array}{l}\text { SMALL } \\
\text { SLAVE } \\
\text { FARMS NEW } \\
\text { SOUTH }\end{array}$ & & & & & & & \\
\hline $\begin{array}{l}\text { PCOT set } \\
\text { at mean }\end{array}$ & -- & -- & 7.475 & 7.359 & 7.582 & -- & -- \\
\hline $\begin{array}{l}\text { PCOT set } \\
\text { at zero }\end{array}$ & 7.438 & -- & 7.535 & 7.008 & 7.407 & -- & -- \\
\hline $\begin{array}{l}\text { LARGE } \\
\text { SLAVE } \\
\text { FARMS OLD } \\
\text { SOUTH }\end{array}$ & & & & & & & \\
\hline $\begin{array}{l}\text { PCOT set } \\
\text { at mean }\end{array}$ & -- & 8.265 & -- & 8.338 & -- & 8.461 & 8.731 \\
\hline $\begin{array}{l}\text { PCOT set } \\
\text { at zero }\end{array}$ & 8.355 & 8.057 & -- & 7.951 & -- & 8.116 & 8.523 \\
\hline $\begin{array}{l}\text { LARGE } \\
\text { SLAVE } \\
\text { FARMS NEW } \\
\text { SOUTH }\end{array}$ & & & & & & & \\
\hline $\begin{array}{l}\text { PCOT set } \\
\text { at mean }\end{array}$ & -- & -- & 8.925 & -- & 8.837 & 8.703 & 9.053 \\
\hline $\begin{array}{l}\text { PCOT set } \\
\text { at zero }\end{array}$ & 8.449 & -- & 9.012 & -- & 8.566 & 8.221 & 8.761 \\
\hline
\end{tabular}

Sources: Bateman-Foust and Parker-Gallman samples. Figures are calculated from stochastic frontier regression results reported in Appendix Table 2 .

Notes: PCOT is the predicted cotton share of output, calculated from the regression results reported in Appendix Table 1. 


\begin{tabular}{|c|l|l|l|l|l|l|l|}
\hline \multicolumn{7}{|c|}{ AVERAGE INEFFICIENCY BY FARM GROUP AND REGION } \\
\hline & $\begin{array}{l}\text { Northern } \\
\text { Farms }\end{array}$ & \multicolumn{2}{|c|}{ Old South } & \multicolumn{3}{l|}{ New South } \\
\hline & & $\begin{array}{l}\text { Free } \\
\text { Farms }\end{array}$ & $\begin{array}{l}\text { Small } \\
\text { Slave } \\
\text { Farms }\end{array}$ & $\begin{array}{l}\text { Large } \\
\text { Slave } \\
\text { Farms }\end{array}$ & $\begin{array}{l}\text { Free } \\
\text { Farms }\end{array}$ & $\begin{array}{l}\text { Small Slave } \\
\text { Farms }\end{array}$ & $\begin{array}{l}\text { Large } \\
\text { Flave } \\
\text { Farms }\end{array}$ \\
\hline $\begin{array}{l}\text { Mean } \\
\text { of } u_{i j}\end{array}$ & 0.296 & 0.383 & 0.302 & 0.363 & 0.468 & 0.406 & 0.471 \\
\hline
\end{tabular}

Sources: Bateman-Foust and Parker-Gallman samples. Figures are calculated from stochastic frontier regression results reported in Appendix Table 2 . 


\begin{tabular}{|l|r|}
\hline \multicolumn{2}{|c|}{ TABLE } \\
ESTIMATED REGRESION COEFFICIENTS \\
(DEPENDENT VARIABLE
\end{tabular}


Sources: Bateman-Foust and Parker-Gallman samples.

Notes: $\quad{ }^{a}$ Calculated from frontier regression results reported in Appendix Table 2 .

NSCOT1 = COTSHARE * a dummy variable which equals one if the farm was in MS, LA, or AL.

NSCOT2 = COTSHARE * a dummy variable which equals one if the farm was in FL or TN.

COTAR

$=$ COTSHARE * $\mathrm{AR}$

cotTx

$=$ COTSHARE * TX

DSLAVE

$=1$ if slaves $>0$

DGANG

$=1$ if slaves $\geq 16$ 


\begin{tabular}{|c|c|c|c|c|c|c|c|}
\hline \multicolumn{8}{|c|}{$\begin{array}{c}\text { TABLE } 5 \\
\text { MEAN PREDICTED REVENUES }\end{array}$} \\
\hline & \multicolumn{7}{|c|}{ Farm Function Used: } \\
\hline $\begin{array}{l}\text { Evaluated } \\
\text { at Means } \\
\text { for: }\end{array}$ & North & $\begin{array}{l}\text { Free } \\
\text { old } \\
\text { South }\end{array}$ & $\begin{array}{c}\text { Free } \\
\text { New } \\
\text { South }\end{array}$ & $\begin{array}{l}\text { Small } \\
\text { Slave } \\
\text { Old } \\
\text { South }\end{array}$ & $\begin{array}{l}\text { Small } \\
\text { Slave } \\
\text { New } \\
\text { South }\end{array}$ & $\begin{array}{l}\text { Large } \\
\text { Slave } \\
\text { old } \\
\text { South }\end{array}$ & $\begin{array}{c}\text { Large } \\
\text { Slave } \\
\text { New } \\
\text { South }\end{array}$ \\
\hline \multicolumn{8}{|l|}{$\begin{array}{l}\text { NORTHERN } \\
\text { FARMS }\end{array}$} \\
\hline $\begin{array}{l}\text { PCoT set } \\
\text { at zero }\end{array}$ & 6.786 & 6.434 & 6.532 & -- & -- & -- & -- \\
\hline \multicolumn{8}{|l|}{$\begin{array}{l}\text { FREE FARMS } \\
\text { OLD SOUTH }\end{array}$} \\
\hline $\begin{array}{l}\text { PCOT } \\
\text { set at } \\
\text { mean }\end{array}$ & -- & 6.062 & 6.048 & -- & -- & -- & -- \\
\hline $\begin{array}{l}\text { PCOT set } \\
\text { at zero }\end{array}$ & 6.275 & 5.899 & 6.005 & -- & -- & -- & -- \\
\hline \multicolumn{8}{|l|}{$\begin{array}{l}\text { FREE FARMS } \\
\text { NEW SOUTH }\end{array}$} \\
\hline $\begin{array}{l}\text { PCOT } \\
\text { set at } \\
\text { mean }\end{array}$ & -- & 6.137 & 6.111 & -- & -- & -- & -- \\
\hline $\begin{array}{l}\text { PCOT set } \\
\text { at zero }\end{array}$ & 6.360 & 5.914 & 6.053 & -- & -- & -- & -- \\
\hline \multicolumn{8}{|l|}{$\begin{array}{l}\text { SMALL } \\
\text { SLAVE } \\
\text { FARMS OLD } \\
\text { SOUTH }\end{array}$} \\
\hline $\begin{array}{l}\text { PCOT set } \\
\text { at mean }\end{array}$ & -- & 6.900 & -- & 6.914 & 6.984 & -- & -- \\
\hline $\begin{array}{l}\text { PCOT set } \\
\text { at zero }\end{array}$ & 7.062 & 6.648 & -- & 6.540 & 6.741 & -- & -- \\
\hline
\end{tabular}




\begin{tabular}{|c|c|c|c|c|c|c|c|}
\hline & \multicolumn{7}{|c|}{$\begin{array}{l}\text { TABLE } 5 \text { (cont.) } \\
\text { Farm Function Used: }\end{array}$} \\
\hline $\begin{array}{l}\text { Evaluated } \\
\text { at Means } \\
\text { for: }\end{array}$ & North & $\begin{array}{l}\text { Free } \\
\text { old } \\
\text { South }\end{array}$ & $\begin{array}{c}\text { Free } \\
\text { New } \\
\text { South }\end{array}$ & $\begin{array}{l}\text { Small } \\
\text { Slave } \\
\text { old } \\
\text { South }\end{array}$ & $\begin{array}{l}\text { Small } \\
\text { Slave } \\
\text { New } \\
\text { South }\end{array}$ & $\begin{array}{l}\text { Large } \\
\text { Slave } \\
\text { Old } \\
\text { South }\end{array}$ & $\begin{array}{l}\text { Large } \\
\text { Slave } \\
\text { New } \\
\text { South }\end{array}$ \\
\hline $\begin{array}{l}\text { SMALL } \\
\text { SLAVE } \\
\text { FARMS NEW } \\
\text { SOUTH }\end{array}$ & & & & & & & \\
\hline $\begin{array}{l}\text { PCOT set } \\
\text { at mean }\end{array}$ & -- & -- & 7.064 & 7.090 & 7.180 & -- & -- \\
\hline $\begin{array}{l}\text { PCOT set } \\
\text { at zero }\end{array}$ & 7.143 & -- & 6.929 & 6.410 & 6.856 & -- & -- \\
\hline $\begin{array}{l}\text { LARGE } \\
\text { SLAVE } \\
\text { FARMS OLD } \\
\text { SOUTH }\end{array}$ & & & & & & & \\
\hline $\begin{array}{l}\text { PCOT set } \\
\text { at mean }\end{array}$ & -- & 8.009 & -- & 7.851 & -- & 8.042 & 8.131 \\
\hline $\begin{array}{l}\text { PCOT set } \\
\text { at zero }\end{array}$ & 8.065 & 7.637 & -- & 7.300 & -- & 7.534 & 7.759 \\
\hline $\begin{array}{l}\text { LARGE } \\
\text { SLAVE } \\
\text { FARMS NEW } \\
\text { SOUTH }\end{array}$ & & & & & & & \\
\hline $\begin{array}{l}\text { PCOT set } \\
\text { at mean }\end{array}$ & -- & -- & 8.632 & -- & 8.307 & 8.529 & 8.591 \\
\hline $\begin{array}{l}\text { PCOT set } \\
\text { at zero }\end{array}$ & 8.165 & -- & 8.549 & -- & 7.806 & 7.788 & 8.069 \\
\hline
\end{tabular}

Sources: Bateman-Foust and Parker-Gallman samples. Figures are calculated from results reported in Tables $2-4$. 


\section{REFERENCES}

Atack, J. and Bateman, F. (1987). To Their Own Soil: Agriculture in the Antebellum North, Ames, IA: Iowa State University Press.

Aigner, D., Knox Lovell, C.A. and Schmidt, P. (1977). Formulation and estimation of stochastic frontier production function models, Journal of Econometrics, 6, 21-38.

David, Paul and Peter Temin (1979). Explaining the relative efficiency of slave agriculture in the south: comment, American Economic Review, 69, 213-218.

Cairnes, Jonathan Elliot [1862] (1962). The Slave Power: Its Character, Career, and Probable Designs, New York: Carleton Press.

Craig, Lee A. (1991). The Value of Household Labor in Antebellum Northern Agriculture, Journal of Economic History, 51, 67-82.

(1993). To Sow One Acre More: Childbearing and Farm Productivity in the Antebellum North, Baltimore: Johns Hopkins University Press.

Craig, Lee and Elizabeth Field-Hendrey (1992). Industrialization and the Earnings Gap, Explorations in Economic History, 30, 60-80.

David, Paul and Peter Temin (1979). Explaining the Relative Efficiency of Slave Agriculture in the Antebellum South: A Comment, American Economic Review, 69, 213-218.

Field, Elizabeth (1985). Elasticities of Complementarity and Returns to Scale in Antebellum Cotton Agriculture. Unpublished dissertation, Duke University.

Field, Elizabeth (1988). The relative efficiency of slavery revisited: a translog production function approach, American Economic Review, 78, 543-9.

Field-Hendrey, Elizabeth (1995). Application of a Stochastic Production Frontier to Slave Agriculture: An Extension, Applied Economics, 27, 363-.

Fogel, Robert and Stanley Engerman (1974). Time on the Cross: The Economics of American Negro Slavery, Boston: Little, Brown and Company.

Gallman, Robert (1970). Self-sufficiency in the Cotton Economy of the Antebellum South, Agricultural History, 44, 5-23.

Grabowski, Richard and Carl Pasurka (1989). The relative efficiency of slave agriculture: an application of a stochastic production frontier, Applied Economics, 21, 587-595. 
(1991). The relative efficiency of slave agriculture: a reply, Applied Economics, 23, 869-870.

Gray, Lewis Cecil (1941). History of Agriculture in the Southern United States to 1860, New York: Peter Smith.

Hofler, Richard and Sherman Folland (1991). The relative efficiency of slave agriculture: a comment, Applied Economics, 23, 861-868.

Jondrow, J., C.A. Knox Lovell, I.S. Materov, and P.Schmidt (1982). On estimation of technical efficiency in the stochastic frontier production function model, Journal of Econometrics, 19, 233-8.

Olmsted, Frederick Law [1861] (1953). The Cotton Kingdom: A Traveller's Observations on Cotton and Slavery in the American Slave States, New York: Alfred Knopf.

Olson, J.A., Schmidt, P. and Waldman, D,.M. (1980). A Monte Carlo study of estimators of stochastic frontier production functions, Journal of Econometrics, 13, 67-82.

Schaefer, Donald (1983). The Effect of the 1859 Crop Year Upon Relative Productivity in the Antebellum Cotton South, Journal of Economic History, 43, 851-865.

Stampp, Kenneth M. (1956). The Peculiar Institution: Slavery in the Antebellum South, New York: Alfred Knopf.

Wright, Gavin (1979). The efficiency of slavery: another interpretation, American Economic Review, 69, 219-26. 
in

岁

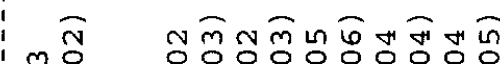

Q

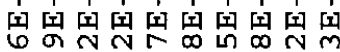
Hन

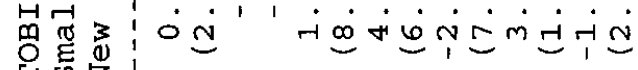

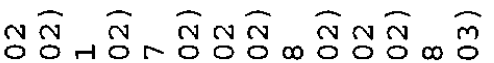

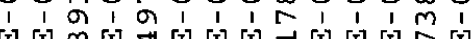

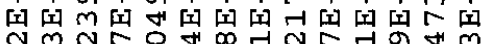
तल

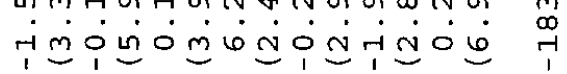

on

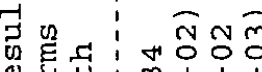

बृ

सम क्य :

r

四

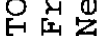

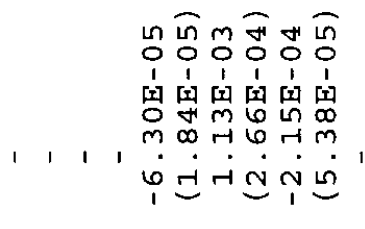

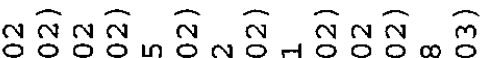

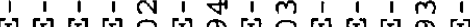

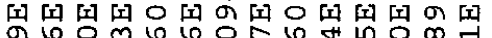

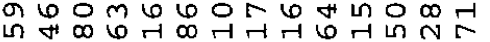

in

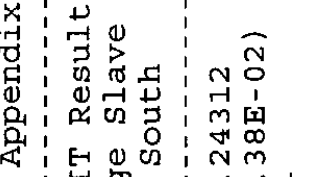

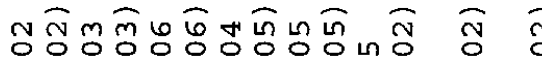
$\begin{array}{lllllll}1 & 1\end{array}$

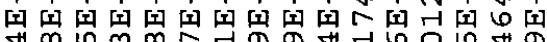
+ in nin

0
$\infty$
1
0
$\dot{m}$
$\infty$
$\infty$
+1
1

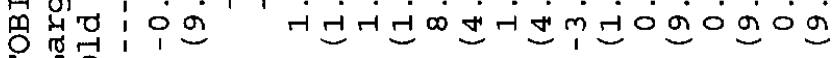
宜实

on

$\stackrel{2}{7}$

\begin{tabular}{l:l:l}
0 & \multirow{2}{*}{} \\
\hdashline & 0
\end{tabular}

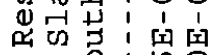

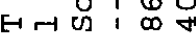

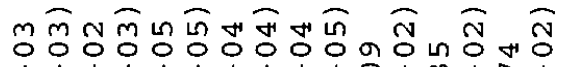

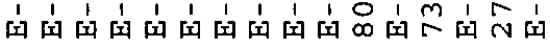

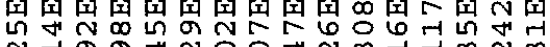

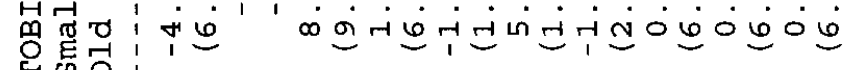

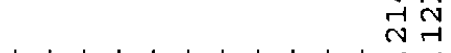

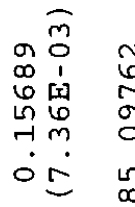

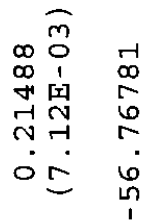

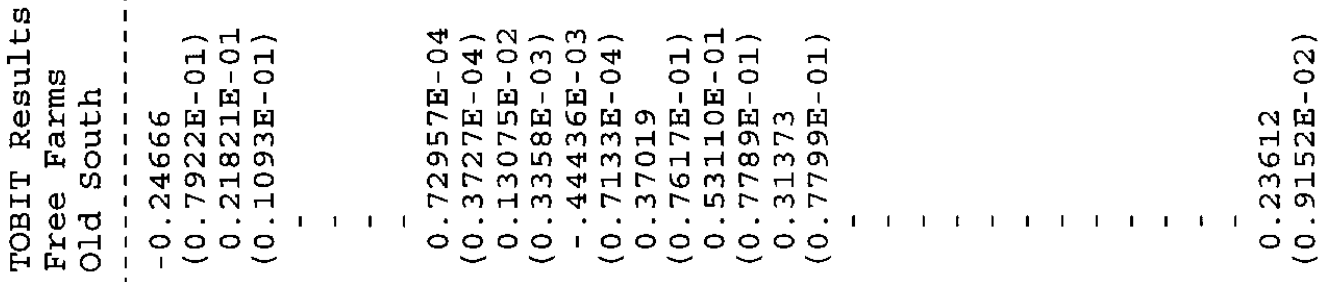

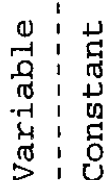

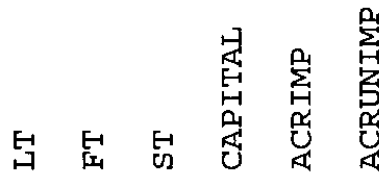

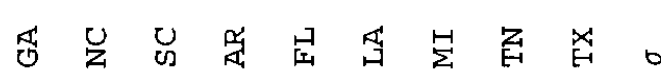




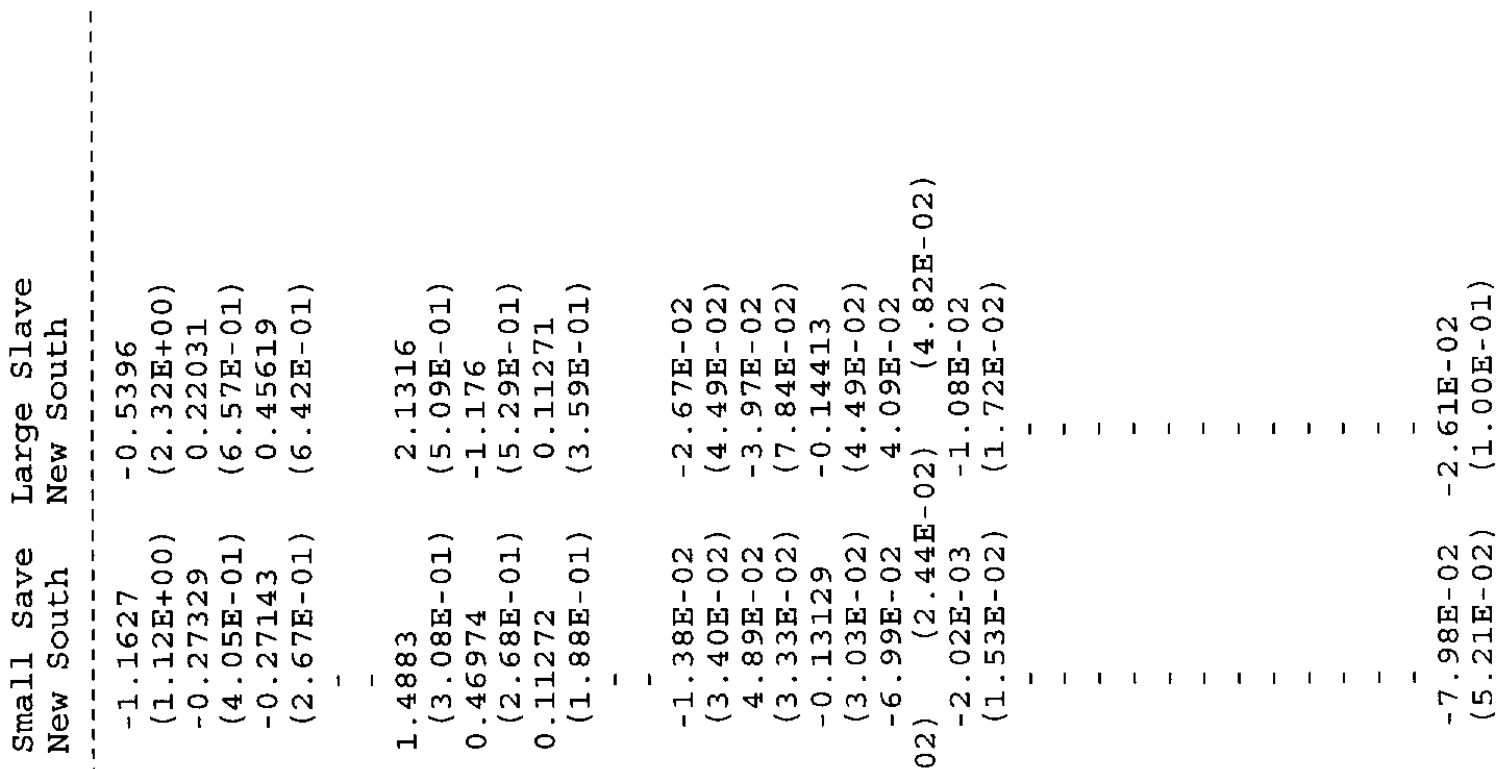

चू

द्या 110

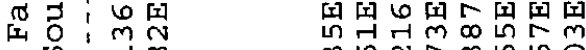

红

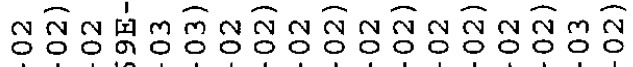

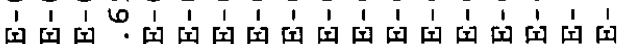

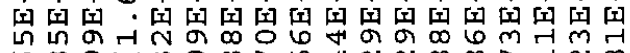
טno

d)

空党

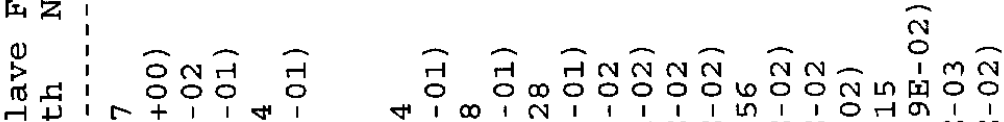

थ

ข

年

मुव

म

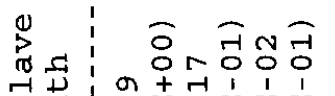

的

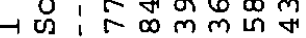

今ิ

m.1

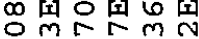

$6006 \mathrm{~mm}$

OัO

ขึิ

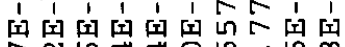

至

要

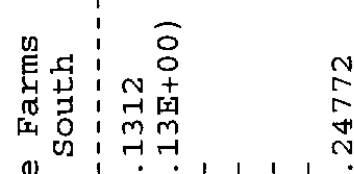

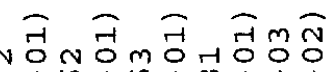

되

†

NGOGmR

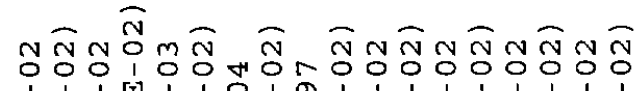

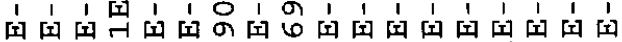

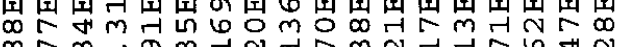

बै

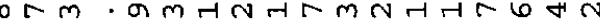

种

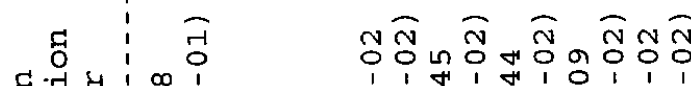

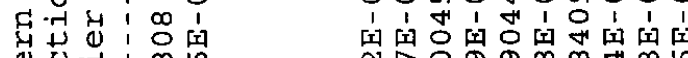

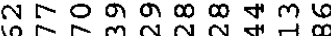

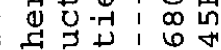
or $m$ mNnt

मे

nंmin

7

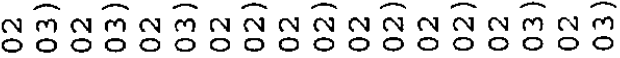
$\begin{array}{lllll}1 & 1 & 1 & 1 & 1 \\ 1 & 1 & 1 & 1 & 1 \\ 1 & 1 & 1 & 1 & 1 \\ 1 & 1\end{array}$

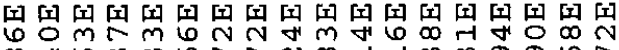

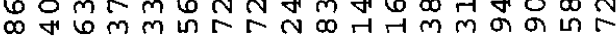
. 


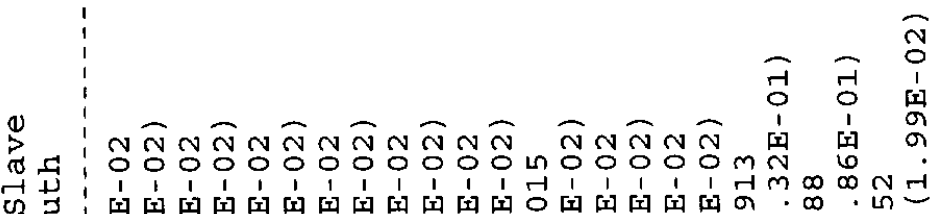

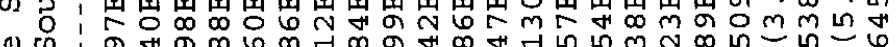

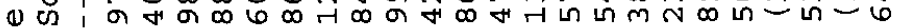

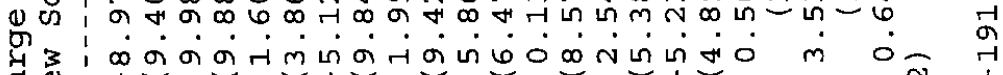

范 1 -

4 กิ

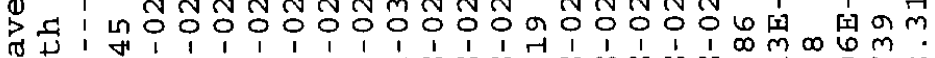

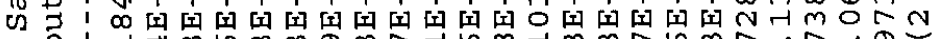

仵

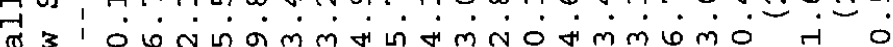

岕

Е

- 1 -

\:

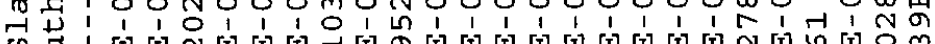
以

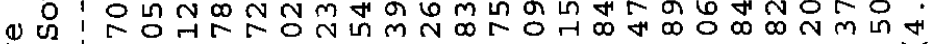
क्व 강

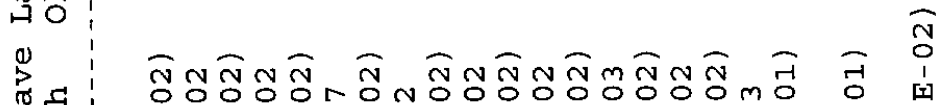

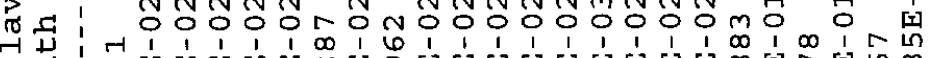

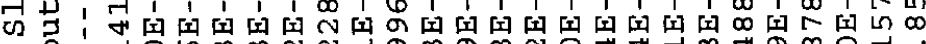
o

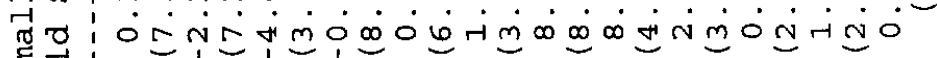
密

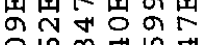

D) in $\operatorname{rim}$

다엉

U $\mathrm{N}$ NOM

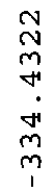

